\title{
Developing Practical Skills Through Blended Learning Model Using Creativity-Based Learning Activites that Enhances Creative Thinking for Education Students Majoring in Social Studies at Mahasarakham University
}

\author{
Sakorn Atthachakara ${ }^{1}$ \\ ${ }^{1}$ Faculty of Education, Mahasarakham University, Thailand \\ Correspondence: Sakorn Atthachakara, Faculty of Education, Mahasarakham University, Thailand.
}

Received: September 7, 2021

Accepted: October 26, 2021

Online Published: November 12, 2021

doi:10.5539/jel.v10n6p126

URL: https://doi.org/10.5539/jel.v10n6p126

\begin{abstract}
The research aimed at: 1) studying practical skills of student teachers majoring in Social Studies at Mahasarakham University through blended learning management using creativity-based learning model that enhances their creative thinking $(\overline{\mathrm{x}}=4.2) ; 2)$ comparing the students' creative thinking abilities before and after learning; 3) investigating the students' satisfaction towards blended learning management through creativity-based learning model. The participants of the study were 30 fourth-year students majoring in Social Studies who were enrolled in Social Study Instructional Media Production course offered in Semester 2 of Academic Year 2020. The purposive sampling technique was employed to obtain the participants. The instruments used in the study include 1) five lesson plans of blended learning management based on creativity-based learning model as to enhance students' creative thinking; 2) creative thinking test; and 3) the 12-item students' satisfaction evaluation form towards blended learning and creativity-based learning model as to enhance creative thinking. The statistics used to analyze the collected data were mean, percentage, standard deviation, and t-test (Dependent Samples).
\end{abstract}

The findings of the study are as follows:

1) After the use of creativity-based learning, it was found that the student teachers majoring in Social Studies at Mahasarakham University obtained 510.20 for the mean score of the post-study activities, 3.28 standard deviation, and 85.10 percent.

2) The comparison of creative thinking before and after learning showed that the students' creative thinking after learning was statistically significantly higher than that before learning at 0.5 level.

3) The students' satisfaction towards blended learning management in the form of creativity-based learning model that promotes creative thinking ability was at high level $(\overline{\mathrm{x}}=4.19)$.

Keywords: practical skills, blended learning, creativity-based learning management, creative thinking

\section{Introduction}

At the present time, teachers' focus is on student-centered learning management which allows students to play roles on teaching and learning activities, take part in discussions, and search for and create their own knowledge and with peers. For this type of teaching and learning, teachers must employ various teaching techniques in order for the students to learn and develop their 21 st century skills: learning and innovation skills, information, media, and technology skills, and life and profession skills. The use of appropriate teaching methods and techniques help students learn mutually. Learning in small groups leads students to work cooperatively as each one can share information, point of view, and experience.

One of the important skills for educational management in the 21 st century is creative thinking. According to the study on creative thinking, it was found that students lacked skills and processes in learning management. They waited for the knowledge from teachers with less self-directed learning. Bangkok University Research Center (2012) found that 98 percent of 994 people believed that creative thinking was beneficial for the country's development. It also stated that universities, schools, and families should take roles in developing creative 
thinking skills as 66.2 percent of people viewed that Thai people lacked creative thinking. Also, Vicharn Panich (2012) pointed out that creative thinking was the skill that Thai people lacked the most. The students taking Professional and Academic Aptitude Test of 1/2017 organized by National Institute of Educational Testing Service obtained low score in creative thinking (NIETS, 2017). Thus, to encourage and train students develop creative thinking will help upgrade students' quality and confidence. Creativity-based learning management focuses on developing learning skills of students, allowing them to seek information freely and creatively. For teachers, they switch their roles from lecturers to facilitators who motivate students to be able to think, present, and work in teams productively (Jongsiriwat \& Fuenta, 2016; Ruchaipanit, 2014).

Obviously, creative thinking skill is not contained in the curriculum. Therefore, it has been rarely taught and learned. However, in 21st Century, it cannot be ignored any longer. As the world is getting more complicated, students must be trained to gain skills that can help them deal with problems that may be come across (Raumkaew, 2011). It is the responsibility of the educational institutions to support and develop students to become qualified learners according to the set standard. The Ministry of Education has also set Qualifications Framework for Bachelor's Degrees in terms of learning qualifications, i.e., 1) morality and ethics, 2) knowledge, 3) intelligence skills, 4) interpersonal relationships and responsibilities, 5) skills, numeral analysis, communication, and implication of information technology, 6) learning management skills (Ministry of Education, 2011). For Mahasarakham University's plans for 2017-2021, its aim of teaching and learning management is to utilize student-centered learning model and focuses on learners' differences. The university promotes students' participations through varieties of learning activities that enhance 21 st century skills. In doing so, students are reliable and assist themselves for living (Mahasakham University Council, 2017).

Blended learning is the learning model that integrates face-to face with online learning and has technology as teaching and learning tools, which helps enhance students' learning. Teaching media attracts students' attention. It is flexible and students are able to learn anywhere and anytime with no limits. It creates interactions between teachers with students, students with students, and students with course contents very well (Wanpiroon \& Nilsook, 2008).

From what has been mentioned above, the researcher realized the importance of necessity of developing the students' creative thinking. Hence, blended learning model using creativity-based learning activities were developed for education students majoring in Social Studies studying at Mahasarakham University. The created model aimed at encouraging and promoting students' practical skills for their future careers. The present research will help improve students' creative thinking and satisfaction towards learning activities. The results will be used as guidelines and implications for teachers to make their teaching and learning more effective.

\section{Purposes of the Research}

1) To study practical skills of education students by using blended learning management in the form of creativity-based learning model that enhances creative thinking.

2) To compare the students' creative thinking before and after learning through blended learning management in the form of creativity-based learning model.

3) To investigate the students' satisfaction towards blended learning management in the form of creativity-based learning model.

\section{Hypothesis of the Research}

The students' creative thinking skill after learning is higher than that before learning through blended learning management in the form of creativity-based learning model.

\section{Research Methodology}

\subsection{Population and Sample}

1) The population consisted of 72 fourth year student teachers majoring in Social Studies in Faculty of Education of Mahasarakham University who were enrolled in 0506448: Social Study Instructional Media Production course.

2) The sample of the study comprised 30 fourth year student teachers majoring in Social Studies in Faculty of Education of Mahasarakham University who were enrolled in 0506448: Social Study Instructional Media Production course. The sample was obtained through purposive sampling technique.

\subsection{Variables}

1) Independent Variable was blended learning management in the form of creativity-based learning for student 
teachers majoring in Social Studies

2) Dependent Variables included

a. Practical skills of the student teachers majoring in Social Studies

b. Creative thinking of the student teachers majoring in Social Studies

c. Satisfaction of the student teachers majoring in Social Studies towards blended learning management in the form of creativity-based learning

\subsection{Learning Contents}

The contents employed in the research were designing, producing, and developing teaching media for Social Studies course which include
1) Printed media
2) Radio and television (sound media)
3) Television (VDO)
4) Multi-media
5) Online application

\subsection{Research Instruments}

The instruments used in the study consisted of

1) 5 teaching plans for 10 hours teaching through blended learning in the form of creativity-based learning which were at high level of appropriateness $(\overline{\mathrm{X}}=4.41$, S.D. 0.57)

2) The creative thinking test which included 3 activities: 1 picture made from an oval-shaped paper, used different lined patterns to complete 10 pictures, and used 30 pairs of parallel lines to draw pictures.

3) The discrimination $\left(\mathrm{r}_{\mathrm{xy}}\right)$ of a 5-point Likert scale questionnaire on satisfaction towards the lessons was between 0.32 and 0.88 and its reliability was 0.84 . It was a 12 -item questionnaire.

\subsection{Research Procedures}

1) The course objectives, learning activities, and evaluation were informed.

2) The pre-test on creative thinking was given.

3) The lesson plans on blended learning using creativity-based learning were employed.

4) The post-test on creative thinking was given.

5) The students' satisfaction towards blended learning management in the form of creativity-based learning was evaluated.

6) The gathered data was analyzed.

\subsection{Data Analysis}

1) The statistics used in the analysis were mean, standard deviation, and percentage.

2) The t-test (dependent samples) was utilized to test the hypothesis on creativity comparison.

3) Mean was used to analyze the students' satisfaction and compared with the criteria (Srisa-ard, 2013).

\section{Research Results}

1) The mean $(\bar{x})$, standard deviation (S.D), and percentage of students' practical skills by using blended learning to promote creative thinking are demonstrated in Table 1. 
Table 1. Mean, Standard Deviation, Percentage, and interpretation of the blended learning management in the form of creativity-based learning that promotes creative thinking

\begin{tabular}{llllll}
\hline Lesson plans & Full Score & Gained Score & $\overline{\mathrm{X}}$ & S.D. & Percentage \\
\hline 1 & 600 & 507 & 16.90 & 0.88 & 84.50 \\
2 & 600 & 508 & 16.93 & 0.69 & 84.67 \\
3 & 600 & 514 & 17.13 & 0.86 & 85.67 \\
4 & 600 & 511 & 17.03 & 0.85 & 85.17 \\
5 & 600 & 513 & 17.10 & 0.85 & 85.50 \\
5 Plans in total & 3000 & 2551 & 510.2 & 3.28 & 85.10 \\
\hline
\end{tabular}

Table 1 shows the students' practical skill mean scores of 510.20 with the full score of 600 . The standard deviation is 3.28 and the percentage is 85.10 . The scores gained in each lesson from the most to the least are Lesson $3(\overline{\mathrm{X}}=17.13$, S.D. $=0.86$, and 85.67\%), Lesson $5(\overline{\mathrm{X}}=17.10$, S.D. $=0.85,85.50 \%)$, Lesson $4(\overline{\mathrm{X}}=17.03$; S.D. $=0.85,85.17 \%)$, Lesson $2(\overline{\mathrm{X}}=16.93$, S.D. $=0.69,84.67 \%)$, and Lesson $1(\overline{\mathrm{X}}=16.90$, S.D. $=0.88$, $84.50 \%)$, respectively.

2) The results of the comparison of the pre-test and post-test scores using t-test (dependent samples) are shown in Table 2.

Table 2. The comparison of the students' creative thinking before and after the lessons of blended learning in the form of creativity-based learning to promote student teachers' creative thinking

\begin{tabular}{lllllll}
\hline Score & $\mathrm{N}$ & $\overline{\mathrm{X}}$ & S.D. & $\mathrm{df}$ & $\mathrm{t}$ & $\mathrm{p}$ \\
\hline Before lessons & 30 & 47.8875 & .18401 & 29 & $25.297^{*}$ & 0.0000 \\
After lessons & 30 & 65.3625 & .64515 & & & \\
\hline
\end{tabular}

Table 2 reveals that the students' creative thinking ability after the lessons is higher than that before the lessons with statistical significance at the 0.5 level. That is, the students' mean score of the pre-test is 47.88 and the post-test mean score is 65.36 . The $\mathrm{t}$-test (dependent samples) was employed for the comparison.

3) The results of students' satisfaction towards the blended learning lessons with the use of creativity-based learning are displayed in Table 3.

Table 3. The results of students' satisfaction towards the blended learning lessons with the use of creativity-based learning for student teachers majoring in Social Studies at Mahasarakham University

\begin{tabular}{llll}
\hline Statement & $\overline{\mathrm{x}}$ & S.D. & Satisfaction Level \\
\hline 1. Satisfaction towards activities provided in the classroom & 4.33 & 0.64 & High \\
2. Satisfaction towards online teaching material & 4.28 & 0.56 & High \\
$\begin{array}{l}\text { 3. Satisfaction towards the process of blended learning management using } \\
\text { creativity-based learning }\end{array}$ & 4.40 & 0.59 & High \\
Overall & 4.33 & 0.60 & High \\
\hline
\end{tabular}

According to Table 3, it is found that overall satisfaction of the students towards blended learning management using creativity-based learning is at high level $(\overline{\mathrm{X}}=4.33$, S.D. $=0.60)$. Individually, the scores arranged from the most to the least are satisfaction towards the process of blended learning management using creativity-based learning $(\overline{\mathrm{X}}=4.40$, S.D. $=0.59)$, satisfaction towards activities provided in the classroom $(\overline{\mathrm{X}}=4.33$, S.D. $=$ $0.64)$, and satisfaction towards online teaching material ( $\overline{\mathrm{X}}=4.28)$, respectively.

\section{Research Results}

1) The mean score of the Social Studies students who learned through 5 blended learning using creativity-based learning lessons was 510.20 with the full score of 600 . The standard deviation and percentage were 3.28 and 85.10 , respectively.

2) The comparison of students' creative thinking ability after the lessons was found higher than that before the lessons with statistical significance at the 0.5 level.

3) The overall satisfaction of the students towards blended learning management using creativity-based activities is at high level $(\overline{\mathrm{X}}=4.33$, S.D. $=0.60)$. 


\section{Conclusion and Discussion}

1) The study of practical skills of the student teachers majoring in Social Studies at Mahasarakham University through blended learning management using creativity-based activities revealed that the students' post-test mean score of the 5 lessons was 510.20 with the full score of 600 . The standard deviation and percentage were 3.28 and 85.10, respectively. It is so because the activities provided were developed and checked for their appropriateness in order to promote students' creative thinking skills. The students were encouraged to create body of knowledge autonomously. Anukulwech (2012) has stated the benefits of blended learning that students have freedom to choose learning contents and learning venues either in classrooms or outside of class. Students can learn on their own according to their levels and learning rates. In addition, students can communicate closely to their teachers. It is the integration between traditional and future learning patterns. The variety of mixed media was utilized in the student-centered learning environment. Moreover, students have time to search for information they need, can analyze and synthesize data well, and receive feedback promptly, which can create learning motivation very well. Teachers can create guidelines for organizing learning activities. Students have time to review the learned lessons and research new knowledge all the time. They can avoid what bothers them in class and that makes them concentrate on their studies more. Also, different teaching patterns, online class and face-to-face teaching, benefit the students who have less self-confidence. The blended learning management takes a variety of teaching and learning strategies and teaching materials are used according to learner differences for them to meet the teaching and learning objectives. The study of Rattanathum (2018) has also found that using blended lesson plans through CIPPA Model promoted undergraduate students' creative thinking at high level. Juthapongtham's study (2018) stated that there were 5 steps in creativity-based learning management, namely, stimulating interests, creating questions and grouping students, researching thoughts, giving presentation, and evaluating. In each step, the activities were organized together with the use of web supported courses in all areas: learning resources, work presentation, work submission, and learning measurement and evaluation.

2) The comparison of students' creative thinking ability after the lessons was found higher than that before the lessons with statistical significance at the 0.5 level. The higher scores the students gained shows that the students understood the blended learning management using creativity-based learning model that enhances creative thinking. Students had chances to create their own body of knowledge. Sariwat (2006) has pointed out that creative thinking is crucial and necessary for humans at the present time because the society changes and progresses in terms of education, science, etc. Those changes are the results of people's creativity. It is shown in Pumahapinyo's study (2016) that Arts students obtained higher visual literacy mean score after learning through blended learning by using cognitive tools with an infographic design approach with statistical significance at .05 level. Chitrakorn (2017), Karnchanachaya (2012), and Rattanatham (2018) have also found the same results on creative thinking improvement after learning through blended learning management.

3) The overall students' satisfaction towards blended learning management using creativity-based activities is at high level $(\overline{\mathrm{X}}=4.33$, S.D. $=0.60)$. It can be stated that the teaching method used in classes enhanced students' creative thinking skills. It focused on promoting students' knowledge and understanding the contents. Students improved their thinking creatively. Additionally, they applied knowledge gained in class into use effectively. There are a number of studies supporting that students are satisfied with the blended learning method using creativity-based learning activities at high level, i.e., Jongsiriwat and Fuenta (2016), Ditsatham (2015), and Sompong and Malithai (2016)

\section{Recommendations from the Research}

\subsection{Implications of Research Results}

1) Before employing the blended learning model with the creativity-based learning activities in the classroom, instructors should study the teaching processes of the model thoroughly.

2) In order to motivate students to have confidence and present their creative thinking effectively, instructors should create relaxed and friendly classroom environment. Also, every student's participation must be considered seriously.

\subsection{Suggestions for Further Studies}

1) The study of the use of blended learning model using creativity-based learning activities should be carried out with students of different levels or students with special needs. The activities provided should also be adjusted to suit the students' ages, abilities, and developments.

2) The blended learning model and creativity-based learning activities developed by the researcher should be 
carried out with other variants, e.g., systematic thinking or critical thinking in order to obtain more reliable and valid results.

\section{References}

Anukulwech, A. (2012). Blended Learning. Retrieved from http://www.chontech.ac.th

Bangkok University Research Center. (2012). Creative Thinking and the Country Development. Retrieved from http://bangkokpoll.bu.ac.th/poll/result/ oll577.php?pollID $=436$

Ditsatham, G. (2015). Research for Learning Innovation Development and Learning Management. The Teachers' Council of Thailand's Academic Conference of 2014. Bangkok: Secretariat Office of the Teachers' Council of Thailand.

Jongsiriwat, S., \& Fuenta, W. (2016). Collection of Research Abstracts of Office of the Permanent Secretary (pp. 144-150). Ministry of Education in the Fiscal Years 2013-2016. Trade Policy and Strategy Office, Office of the Permanent Secretary, Ministry of Education.

Juthapongtham, W. (2018). The Promotion of Creative Thinking by Using Creativity-based Learning with Web-based Courses in Graphic Program Usage Course for Mattayom Suksa 6 Students. Master's Degree Thesis. Maha Sarakham: Maha Sarakham Rajabhat University.

Kanchanachaya, N. (2012). Development of a Blended Learning Model Based on Creative Problem-Solving Principles Using Lateral Thinking to Enhance Creative Problem-Solving Abilities for Instructional Media Production of Pre-service Teachers. Doctoral Degree Dissertation, Chulalongkorn University. Bangkok: Chulalongkorn University.

Mahasarakham University Council. (2017). Mahasarakham University's 12th Educational Development Plan (2017-2021). Maha Sarakham: Mahasarakham University.

Ministry of Education. (2011). Qualifications for Bachelor's Degrees in Education (5-Year Curriculum).

Panich, W. (2012). Ways to Create Learning for Students in 21st Century. Bangkok: Sodsri-Saritwong Foundation.

Rattanathum, P. (2018). Development Learning Activities Blended Learning in the form of CIPPAT hat promotes creativity for undergraduate students. Master's Degree Thesis. Maha Sarakham: Mahasarakham Rajabhat University.

Raumkaew, K. (2011). Effects of Network Learning Environment Based on Constructivist Concepts that Promotes Creative Thinking: Information System Development for Third Year Undergraduate Students Majoring in Computer Studies. Khon Kaen: Khon Kaen University.

Ruechaiphanit, W. (2012, September 22). Guidelines for Teaching and Learning in Preparation for ASEAN [VDO File]. Retrieved from http://www.youtu.be /o6k5LTylqDM

Sariwat, L. (2016). Thinking. Bangkok: Odeon Store.

Sompong, A., \& Malithai, L. (2017). A Study of Teaching and Learning Management by Using Creativity-based Learning in Studying Document and Evidence in History Course. Faculty of Education, Sakon Nakhon Rajabhat University.

Wannapiroon, P., \& Nilsook, P. (2008). Development of a Problem-Based Blended Learning Model to Develop Undergraduate Students' Critical Thinking. Doctoral Degree Dissertation, Technology and Communication Studies, Faculty of Education, Chulalongkorn University.

\section{Copyrights}

Copyright for this article is retained by the author, with first publication rights granted to the journal.

This is an open-access article distributed under the terms and conditions of the Creative Commons Attribution license (http://creativecommons.org/licenses/by/4.0/). 